\title{
Strategi Budaya dalam Filsafat Erich Fromm
}

\author{
Oleh: \\ Fatrawati Kumari
}

\begin{abstract}
The aim of this study is to determine the formulation of Fromm's cultural strategy and find its relevance to national cultural strategy. This qualitative -philosophical study is presented through the synthesis analysis of the psychoanalyst Freud and socio-economist Marx. The conclusion is that the formulation of Fromm's culture strategy rooted in the concept of to be. To be is a way of being existential human, characterized by being active, that is the optimal use of the human strengths for productivity, which tends to make changes and is interested in goodness, also tends to give and love. The cultural strategy is then formulated from the concept of to be. This is an attempt to create a new culture which includes material and non-material aspects. Material aspects include social, economic and political structure, while the non-material aspects includes individual-social character, ideas and objectives of the community in the form of norms, values, dogma, ideology and so forth. These aspects are interacting and influencing each other. The orientation of to be will affect the economic structure, and then form a social character and subsequently form an idea. Furthermore, the cycle runs in reverse in the relational dynamic series.
\end{abstract}

Abstrak: Tujuan kajian ini adalah untuk mengetahui rumusan strategi budaya Fromm dan menemukan relevansinya dengan strategi budaya nasional. Kajian kualitatif-filosofis ini dikemukakan melalui analisis sintesis psikoanalis Freud dan sosio-ekonomis Marx. Adapun kesimpulan yang dihasilkan adalah, bahwa rumusan strategi budaya Fromm berakar dari konsep mengada (to be). Mengada sebagai sebuah cara berada eksistensial manusia bercirikan aktif, yaitu optimal menggunakan kekuatan-kekuatan manusiawi untuk produktif, yaitu cenderung membuat perubahan, menaruh minat terhadap kebaikan, selalu memberi dan mencintai. Berangkat dari konsep mengada tersebut dibangun rumusan strategi budaya, yaitu suatu usaha menciptakan kebudayaan baru meliputi aspek material dan non-material. Aspek material meliputi: struktur sosial, ekonomi dan politik, sedangkan aspek non-material meliputi: karakter individual-sosial, gagasan dan tujuan masyarakat yang berupa: norma-norma, nilai-nilai, dogma, ideologi dan lain sebagainya. Aspek-aspek tersebut saling berinteraksi dan saling mempengaruhi. Orientasi mengada akan mempengaruhi struktur ekonomi, kemudian membentuk karakter sosial dan selanjutnya membentuk gagasan. 
Kemudian siklus berjalan sebaliknya dalam rangkaian relasional yang dinamis. Kata kunci: strategi budaya, mengada, aktif.

\section{Pendahuluan}

Sejak abad kesembilan belas dan dua puluh, terjadi perubahan pesat dimana kebebasan yang tidak terbatas telah dirasakan masyarakat dunia sampai saat ini. Meski demikian, kebebasan ternyata memunculkan adanya sikap mendua. Di satu sisi membawa pada kemandirian dan sikap rasional, namun di sisi lain menimbulkan persoalan karakterologis seperti cemas dan alienasi. ${ }^{1}$ Alienasi adalah suatu keadaan dimana psikis individu-individu mengalami keterasingan baik dari lingkungan maupun dari dirinya sendiri karena tidak lagi merasa sebagai pusat dunia yang menciptakan aktivitas-aktivitasnya secara otonom, melainkan hanya sebagai objek dari tindakannya sendiri. ${ }^{2}$ Inilah yang disebut dengan "kegagalan janji besar" kemajuan industri. ${ }^{3}$ Kesadaran atas persoalan tersebut dibuat pembangunan sebuah strategi budaya yang dianggap dapat mengurai persoalan karakterologis. Karl Marx menawarkan analisis materialis tentang perubahan sejarah. ${ }^{4}$ Kemudian diikuti Madzhab Frankfurt dengan pendekatan neo-Marxian yang menawarkan masyarakat ideal kritis melalui pendekatan multidisiplin yang tidak saja mengandalkan pendekatan sosial-ekonomi, melainkan juga psikoanalisa Freud. ${ }^{5}$

Erich Fromm merupakan filsuf madzhab Frankfrurt yang memperkenalkan psikoanalisa selain untuk mempertajam kritik ideologi yang selama ini menjadi perhatian madzhab Frankfurt, juga untuk memberi penjelasan tentang mengapa kesadaran ditentukan oleh kenyataan dan mengapa kelompok proletar yang dulu revolusioner, kini tidak menampakkan sikap tersebut. Psikoanalisa dianggap dapat menjelaskan dengan tepat hubungan antara "basis ekonomi" (kehidupan material yang real) dengan "bangunan atas" kesadaran manusia."

1 Erich Fromm, Lari Dari Kebehasan, terj. Kamdani, (Yogyakarta: Pustaka Pelajar Ofset, 1999), h..iv.

2 Erich Fromm, Masyarakat yang Sehat, terj. Thomas Bambang Murtianto, (Jakarta: Yayasan Obor Indonesia, 1995), edisi pertama, h. 131.

3 Erich Fromm, To Have or To Be, (USA: Bantham Book, 1981), edition 1, h. xxivxxv.

4 Doyle Paul Johnson, Teori Sosiohgi, Klasik dan Modern, terj. Robert M.Z. Lawang, (Jakarta: Gramedia,1994), h.132.

5 Sindhunata, Dilema Usaha Manusia Rasional, (Jakarta: Gramedia, 1983), h. 53-55.

6 Sindhunata, Dilema Usaha Manusia Rasional, h.56, 60. 
Psikoanalisa juga dapat menunjukkan "apa yang terbaik bagi manusia", bukan "apa yang terbaik untuk sistem". 7 Akar dari persoalan tersebut menurut Fromm adalah dominasi orientasi "memiliki" yang cenderung memperlakukan segala sesuatu sebagai objek (penguasaan). Memiliki sebagai hasil ciptaan sistem ekonomi kapitalisme telah menjadi budaya, model perilaku masyarakat dan karakter sosial yang cenderung menguasai dan menjadikan apa yang dimiliki sebagai hak pribadi serta memperlakukan segala sesuatu sebagai objek. Model relasi yang terbentuk bersifat pasif, statis dan mati. Bentuk relasi ini mereduksi seluruh hubungan manusia, baik ekonomi, sosial, politik maupun keagamaan. ${ }^{8}$

Fromm membangun strategi budaya yang berangkat dari pemahaman atas persoalan individu dan perilaku masyarakat yang dikenal dengan istilah "mengada" (to be), yaitu suatu model eksistensi atau suatu cara berada manusia secara eksistensial (khas manusia) yang bersifat mandiri, bebas dan kritis. ${ }^{9}$ Karakteristik fundamentalnya adalah aktif secara lahir dan batin, yaitu mengekspresikan segenap kemampuan dan bakat-bakat manusiawi untuk senantiasa memperbaharui diri sendiri, selalu tumbuh berkembang, mengalir, mengatasi penjara ego, penuh minat, memberi dan mencintai. ${ }^{10}$ Bagi perspektif mengada, aku didefinisikan sebagai siapa aku, bukan apa yang aku miliki. Aku adalah otonom sebagaimana digambarkan Fromm: ${ }^{11}$ "The anxiety and insecurity engendered by the danger of losing what one has are absent in the being mode. If I am who I am and not what I have, nobody can deprive me of or threaten my security and my sense of identity. My center is within myself; my capacity for being and for expressing my essential power is part of my character structure and depends on me." (Kecemasan dan rasa tidak aman yang ditimbulkan oleh bahaya akan kehilangan apa yang dimiliki, tidak ada dalam model "mengada". Jika aku adalah siapa aku dan bukan apa yang aku miliki, maka tidak seorang pun yang dapat mengancam keamananku dan kesadaran akan identitasku. Pusat aku terdapat dalam diriku; dalam kemampuanku untuk mengada dan untuk mengungkapkan kekuatankekuatanku yang esensial adalah merupakan bagian dari struktur watakku dan tergantung kepadaku). ${ }^{12}$ Mengada berusaha

7 Erich Fromm, To Have or To Be, h. xxix.

8 Erich Fromm, To Have or To Be, h. 65.

9 Erich Fromm, Manusia Bagi Dirinya, terj. Eno Syafruddin, Jakarta: Akademika, 1988), h. 45.

${ }^{10}$ Erich Fromm, 1963, The Art of Loving, (USA: Bantam, 1963), h. 2-32.

${ }^{11}$ Erich Fromm, To Have or To Be, h. 97.

${ }^{12}$ Erich Fromm, To Have or To Be, h. 97. 
mengembalikan individu pada kekuatan yang terdapat dalam diri sendiri, bukan pada sesuatu yang berada di luar diri. Mengada mengempatkan manusia sebagai sosok otonom, tidak terpengaruh oleh fluktuasi kenyataan luar sebab segala sesuatu yang ada dalam diri bersifat tetap dan melekat. Secara otomatis segala persoalan eksistensial yang terdapat pada memiliki seperti kecemasan dan alienasi tidak ditemukan karena yang ada berupa dinamikanya yang sehat, aktif, produktif yang berimplikasi pada terwujudnya situasi aman, damai dan tenteram.

Meskipun konsep mengada telah dikemukakan filsuf sebelumnya (Gabriel Marcel, 1889) dengan corak eksistensialis, namun di tangan Fromm, mengada tidak sekedar menyentuh sisi individual-eksistensialis, melainkan juga psikoanalis dan sosiologis yang pada gilirannya mampu melahirkan sebuah rumusan strategi budaya. Melalui pendekatannya yang komprehensif tersebut, tawaran strategi budaya Fromm memiliki pijakan kuat karena berlandaskan pendekatan psikoanalis sekaligus sosiologis. Keunggulan strategi budaya Fromm lain adalah bahwa ia bukan sekedar sebuah upaya penyusunan kebijakan baru tentang kebudayaan yang bersifat material, melainkan mencakup segala hal yang berada di belakang perubahan kebijakan (policy) kebudayaan mencakup: tujuan hidup, makna hidup, norma-norma dan lain sebagainya. ${ }^{13}$ Dengan kata lain, strategi budayanya menyentuh seluruh struktur fundamental pembangunan budaya, yaitu strukur sosial, struktur ekonomi dan karakter sosial. ${ }^{14}$ Dalam konteks ini lah pandangan strategi budaya Fromm perlu dikaji secara khusus dalam pembahasan ini. Adapun hal yang dibahas mencakup konsep strategi budaya Fromm dan relevansinya dengan strategi budaya Nasional.

\section{Strategi Budaya}

Pandangan strategi budaya Fromm berpangkal pada konsep mengada (being). Strategi budaya adalah suatu usaha menciptakan kebudayaan baru meliputi banyak dimensi mencakup usaha menyusun ketentuan-ketentuan tentang tatanan kebudayaan baru dan juga meliputi segala sesuatu yang berada di belakang ketentuan tatanan tersebut, seperti tujuan hidup, makna hidup dan norma-norma. Strategi budaya juga didefinisikan Fromm sebagai suatu usaha perubahan dan

${ }^{13}$ Van Peursen, Strategi Kebudayaan, terj. "Strategic Van De Cultuur", Dick Hartoko, (Kanisius, Yogyakarta, 1988), h. 19.

14 Anton Bakker, 1992, Ontologi atau Metafisika Umum, (Yogyakarta: Kanisius, 1992), lihat pula Erich Fromm, To Have or To Be, h. 12-13. 
pembaharuan yang menyentuh beberapa aspek fundamental masyarakat, yaitu aspek material dan non-material. Aspek material meliputi: struktur sosial, ekonomi, politik dan lain sebagainya, adapun aspek non-material meliputi: karakter individual-sosial dan gagasan-tujuan masyarakat, seperti berupa: norma-norma, nilai-nilai, dogma, ideologi dan lain sebagainya. Aspek-aspek tersebut saling berinteraksi dan saling mempengaruhi. ${ }^{15}$

Mengada sebagai sebuah cara berada eksistensial manusia, dalam perwujudannya, memerlukan suasana kemandirian dan kebebasan agar peran aktif individu dapat tumbuh dengan baik. Aktif berarti optimal menggunakan kekuatan-kekuatan manusiawi untuk produktif, yaitu kecenderungan membuat perubahan dan terobosan-terobosan, menaruh minat terhadap kebaikan, selalu memberi dan mencintai. ${ }^{16}$ Usaha perubahan (untuk diri dan orang lain) dapat menyelamatkan diri keluar dari apa yang disebut Fromm dengan "bahaya psikologis" dan "bahaya ekonomis" sebagaimana yang diungkapkannya:

"...only a fundamental chance in human character from a preponderance of the having mode to a predominantly being mode of existence can save us from a psychologic and economic catastrophe.." (hanya perubahan fundamental dalam karakter manusia dari kekuasaan model memiliki ke eksistensi model mengada yang utama, dapat menjaga manusia dari bahaya psikologis dan ekonomis). ${ }^{17}$

Bahaya ekonomis yaitu kecenderungan yang bertumpu pada hak milik, keuntungan dan kekuasaan yang berimplikasi pada penindasan dan kekerasan, sedangkan bahaya psikologis dapat berbentuk perasaan kesepian, kecemasan dan alienasi. Bahaya psikologis bisa pula terjadi ketika bahaya ekonomis tersebut oleh masyarakat tidak dirasakan sebagai bahaya karena orientasi memiliki telah merasuk ke segenap sisi psikologis mereka. Kesadaran atas bahaya-bahaya tersebut mendorong manusia untuk melakukan perubahan secara individual dan sosial. Dengan demikian, akar persoalan yang menimpa masyarakat berpangkal pada masalah karakterologis, sehingga perubahan yang dilakukan juga menyentuh persoalan karakterologis. Inilah yang disebut dengan perubahan karakter. Kondisi yang memungkinkan bagi perubahan

\footnotetext{
${ }^{15}$ Van Peursen, Strategi Kebudayaan, h. 19.

${ }^{16}$ Erich Fromm, To Have or To Be, h. 76.

${ }^{17}$ Erich Fromm, To Have or To Be, h. 153.
} 
karakter bisa bersifat individual, dapat pula bersifat sosial. Manusia dapat dipengaruhi dan sekaligus dapat mempengaruhi lingkungan yang melingkupinya sesuai dengan karakter manusia yang mampu membentuk kondisi-kondisi sosial dimana manusia tersebut berada. Kebutuhan untuk mencari sesuatu yang lebih baik seperti kebahagiaan, kebebasan, keadilan dan lain sebagainya, merupakan sesuatu yang melekat dalam sifat manusia. Kebutuhan ini juga menjadi faktor-faktor dinamis yang terdapat dalam sebuah proses sejarah manusia yang akan menguat ketika berada dalam situasi represif. Begitu pentingnya hal ini, sehingga jika suatu tatanan sosial mengabaikan atau menghalangi usaha pemenuhan atas kebutuhan ini dalam batas tertentu, maka manusia yang berada di dalamnya akan membentuk perlawanan dengan mengubah tatanan sosial agar lebih sesuai dengan kebutuhan dasarnya sebagai manusia. ${ }^{18}$

Jika perubahan sosial tidak dapat dilakukan, maka menurut Fromm kelompok masyarakat yang ada kemungkinan besar akan hancur. Perkembangan kebutuhan menuntut adanya perubahan yang dapat mengimbangi perkembangan tersebut. Oleh karena itu, menciptakan kondisi material yang mendukung perubahan sosial adalah niscaya. Kondisi-kondisi tersebut meliputi struktur-struktur sosial, ekonomi dan politik. Struktur ekonomi menjadi fundamental bagi manusia yang menuntut perbaikan. Adapun strategi kebudayaan dilakukan mengiringi perkembangan masyarakat yang di dalamnya terdapat karakter dan struktur sosial yang saling berhubungan secara dinamis dan berkelanjutan. ${ }^{19}$ Sebagaimana yang ditunjukkan Fromm, bahwa masyarakat industri kapitalis telah didominasi oleh orientasi "memiliki" dan telah menjadi kebudayaan sehingga tercipta 'karakter pasar'. Pada saat yang sama, karakter sosial (pasar) menciptakan gagasan dan tujuantujuan yang bercorak kapitalis pula. Kemudian gagasan berpengaruhbalik dalam menciptakan karakter sosial dan karakter sosial menciptakan struktur ekonomi. Karakter sosial menjadi mediasi (perantara) antara struktur ekonomi dan gagasan. Karakter sosial merupakan perantara dua arah dari struktur ekonomi menuju gagasan dan dari gagasan menuju struktur ekonomi. ${ }^{20}$

Siklus ketiga unsur tersebut berproses secara terus-menerus dan menunjukkan, bahwa karakter sosial diciptakan oleh cara berada

\footnotetext{
${ }^{18}$ Erich Fromm, To Have or To Be, h.108-109.

${ }^{19}$ Erich Fromm, To Have or To Be, h.120..

${ }^{20}$ Erich Fromm, Beyond the Chains of Illusion, h. 116.
} 
masyarakat, terutama cara berada secara ekonomi. Unsur-unsur tersebut merupakan adaptasi dinamis dari karakter manusia terhadap struktur yang terdapat di masyarakat. Masyarakat didorong untuk bertindak sesuai dengan kebutuhan ekonomi modern. Dorongan tersebut berupa kompulsi-dalam yang sangat kuat 'memaksa' masyarakat untuk melakukan sesuatu sesuai struktur ekonomi yang berlaku. Sebagai contoh, karakter sosial: reseptif, eksploitatif dan menimbun merupakan hasil konkret bentukan sistem ekonomi kapitalis. Contoh karakter sosial menciptakan gagasan adalah masyarakat dengan karakter feodal, akan mengarahkan gagasan dan tujuan tindakannya pada hal-hal seperti: stabilitas atas tatanan tradisional, hubungan yang harmonis dengan majikan dan konsep tentang Tuhan sebagai penjamin akhir dari stabilitas sistem feodal. Jika salah satu atau beberapa gagasan tersebut diserang, maka anggota masyarakat tersebut akan berusaha mempertahankan, bahkan bersedia mengorbankan nyawa untuk mempertahankan apa yang dianggapnya sebagai keyakinan. Demikian pula sebaliknya, gagasan atau pandangan dan tujuan suatu masyarakat dapat membentuk karakter. Masyarakat yang memiliki gagasan-gagasan kapitalistik, akan membentuk karakter yang bercorak kapitalistik pula. ${ }^{21}$

Struktur ekonomi menciptakan gagasan, diilustrasikan dalam beberapa contoh yang mengungkapkan kenyataan, bagaimana gagasangagasan tertentu berakar dan merepresentasikan suatu struktur ekonomi masyarakat. Masyarakat dengan struktur ekonomi kapitalis abad ke-19 telah menciptakan gagasan tentang "inisiatif individu". Kapitalisme abad ke-20 menciptakan gagasan "hubungan manusia". Pada masyarakat kapitalis umumnya, "keadilan" menjadi norma paling populer yang berhasil diciptakan. Selanjutnya gagasan menciptakan struktur ekonomi ketika prinsip tersebut mereka gunakan sebagai hukum dasar pasar bebas di mana komoditas dan tenaga kerja dipertukarkan tanpa pemaksaan. ${ }^{22}$

Seluruh relasi antara struktur ekonomi, karakter sosial dan gagasan sebagaimana yang telah dijelaskan, didominasi oleh orientasi "memiliki". Orientasi memiliki bersifat non-produktif sehingga perlu diciptakan sebuah transisi, dari kebudayaan memiliki kepada kebudayaan mengada. ${ }^{23}$ Sebagaimana yang telah dikemukakan, bahwa karakter sosial merupakan mediasi antara struktur ekonomi dan gagasan. Karakter sosial "memiliki" yang terbentuk, telah menjadi mediasi yang

\footnotetext{
${ }^{21}$ Erich Fromm, Beyond the Chains of Illusion, h. 112-113.

${ }^{22}$ Erich Fromm,, Beyond the Chains of Illusion, h. 115.

${ }^{23}$ Sastrapratedja, 1987, Orientasi Hidup: Memilikei atau Mengada?, xxxvi.
} 
efektif bagi pembentukan struktur ekonomi dan gagasan masyarakat modern kapitalis. Usaha transisi yang dilakukan adalah usaha yang dapat menyelesaikan tersebut bersifat karakterologis, yaitu dengan mengajukan strategi budaya yang berpijak pada orientasi "mengada".

Mengada akan mewarnai seluruh siklus perkembangan. Pertama, mengada akan ditempatkan pada posisi karakter sosial, menggantikan karakter sosial "memiliki” yang berlaku sebelumnya. Kedua, perubahan karakterologis perlu didukung dengan perubahan-perubahan lain, terutama perubahan struktur ekonomi. Adapun struktur ekonomi yang akan diberlakukan adalah struktur ekonomi mengada yang merupakan hasil sintesis antara sistem kapitalisme, sosialisme dan humanisme. Jika struktur tersebut telah dipenuhi orientasi mengada, maka gagasan dan tujuan sosial, akan terbentuk sebagaimana dua kecenderungan yang ada. Terlebih lagi, karena karakter sosial menjadi satu-satunya unsur yang bersinggungan dengan gagasan, maka dapat dipastikan, bahwa gagasan yang terbentuk akan berorientasi mengada. Proses ini secara jelas digambarkan sebagai berikut: ${ }^{24}$

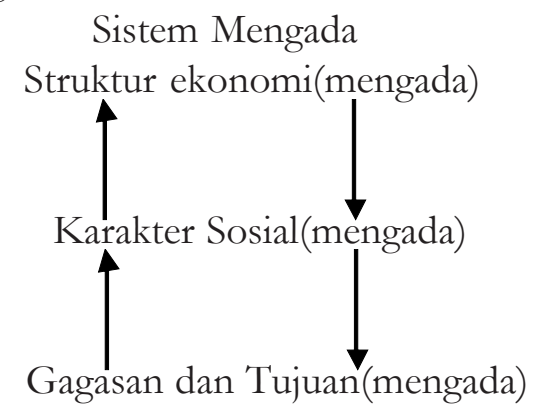

Karakter sosial tetap dalam posisinya sebagai mediator dua struktur yang ada. Karakter sosial berada dalam posisi penting karena secara otonom dapat membentuk keduanya. Siklus tidak berubah, tetapi yang berubah adalah dominasi. Jika sebelumnya siklus didominasi "memiliki", maka kini didominasi "mengada". Kesediaan untuk membuang semua bentuk dominasi "memiliki" dan sepenuhnya "mengada" merupakan kecenderungan karakteristik utama masyarakat baru yang dikemukakan Fromm. Fungsi masyarakat baru ini akan mendorong lahirnya manusia baru. Masyarakat baru adalah masyarakat sehat, diantara ciri-cirinya adalah masyarakat yang realistis, yaitu bebas dari ilusi-ilusi yang diciptakan modernitas, seperti: kebebasan dan kesenangan. Realistis juga berarti sadar sepenuhnya akan persoalan dan kesulitan yang ada. Fromm menyebut hal ini sebagai "utopia yang sadar" (awake utopian) yang

${ }^{24}$ Erich Fromm, To Have or To Be, h.159-160. 
dibedakannya dengan utopia yang mimpi" (dreaming utopian). Utopia sadar adalah utopia yang diciptakan secara sadar yang berpeluang besar untuk diwujudkan sebagaimana kenyataan utopia teknik, seperti penerbangan yang sebelumnya dianggap mustahil. Fromm juga menyebut gagasannya sebagai utopia kemanusiaan yang dengan mengada akan mewujudkan masyarakat baru yang lebih baik yang didalamnya terdapat manusia baru yang dipenuhi dengan solidaritas, perdamaian, kesejahteraan, bebas dari determinasi ekonomi - peperangan dan perjuangan kelas.

Fromm menggambarkan masyarakat sehat sebagai suatu keadaan yang sejalan dengan kebutuhan manusia dan berakar dari dalam kondisi eksistensinya. Masyarakat sehat adalah suatu masyarakat yang manusianya saling menjalin hubungan dengan cinta, dalam ikatan persaudaraan dan solidaritas, bukan dalam ikatan-ikatan darah atau tanah air. Masyarakat model ini memberikan peluang besar bagi individu untuk mengatasi alam dengan mencipta, bukan dengan menghancurkan dan memungkinkan bagi tiap individu untuk memperoleh pemahaman akan jati dirinya lewat pengalaman sendiri sebagai subjek dengan segenap kekuatan-kekuatan diri, bukan ikut arus untuk kompromi atau untuk mengabdi dan membelokkan kenyataan dengan menyembah berhala-berhala dalam berbagai bentuk. Masyarakat sehat merupakan hasil konkret dari usaha strategi budaya. ${ }^{25}$ Fromm memasukkan masyarakat sehat ke dalam sebuah kebudayaan ideal kemudian mengistilahkannya "Sssialisme komuniter humanistik" yang merupakan sintesis antara kapitalisme, komunisme dan humanisme. ${ }^{26}$ Fromm menyebutkan pula, bahwa kebudayaan yang dimaksudkan merupakan sintesis antara kebudayaan abad pertengahan bagian akhir dengan kebudayaan modern. Kebudayaan abad pertengahan (akhir) memiliki visi tentang Kota Allah (City of God), sementara kebudayaan masyarakat modern mempunyai visi tentang Kota Kemajuan Duniawi (Earthly City of God). Fromm menyebut kota ini dengan Kota Mengada (The City of Being), yaitu sintesis antara inti spiritual dari dunia pertengahan dengan perkembangan pemikiran rasional dan ilmu pengetahuan sejak masa renaissance. ${ }^{27}$

Beberapa hal yang mempengaruhi usaha membentuk strategi budaya. Pertama adalah kesadaran karena menjadi kata kunci bagi perubahan sosial. Segala kondisi dan kenyataan pada gilirannya

${ }^{25}$ Erich Fromm, Masyarakatyang Sehat, h. 410.

${ }^{26}$ Erich Fromm, Masyarakat yang Sehat, h. 410.

${ }^{27}$ Erich Fromm, To Have or To Be, h.187. 
bertumpu pada kesadaran. Kesadaran merupakan elemen terpenting yang dapat menggerakkan manusia dari satu keadaan kepada keadaan yang lain. Fromm menempatkan kesadaran pada urutan pertama dari usaha strategi budaya, yaitu sadar akan persoalan atau penderitaan yang dialami, kemudian menelusuri akar persoalan tersebut, mencari jalan keluar, bersedia mengikuti pola atau norma-norma hidup "mengada" dan mengubah praktek hidup yang berlaku saat ini. Secara berurutan keempat urutan tersebut adalah: 1) menyadari kenyataan akan persoalan dan penderitaan yang terjadi; 2) mengenali asal penderitaan tersebut; 3) mengetahui bahwa ada cara atau jalan untuk mengatasi penderitaan; 4) mengikuti norma-norma hidup tertentu (mengada) dan mengubah praktek hidup yang dijalani sebelumnya (memiliki). Fromm mengambil keempat hal tersebut dari Empat Kebenaran Mulia yang merupakan dasar ajaran Budha. Menurutnya, ide Marx tentang penyelamatan (salvation) juga didasari oleh ajaran Budha tersebut, dimana kelas pekerja yang paling teralienasi merupakan subyeknya. Demikian pula Frued, mengambil hal yang sama untuk penyembuhan pasiennya. ${ }^{28}$

Kesadaran akan mengarahkan manusia pada model eksistensi yang lebih hakiki yaitu mengada. Bermula dari kesadaran akan krisis 'kemanusiaan' yang diakibatkan oleh perkembangan ekonomi modern, kemudian menggerakkan individu untuk memecahkan persoalan, memperbaiki keadaan diri dan lingkungannya dan seterusnya menetapkan mengada sebagai model eksistensi diri. Fromm meyakini, bahwa masa depan manusia tergantung pada ada atau tidak kesadaran akan krisis yang dihadapinya (It is my conviction that our future depends on whether, given awareness of the present crisis...their concerted effort will help to solve the problems already mentioned here and to achieve the goals..). ${ }^{29}$ Karena pentingnya kesadaran, Fromm menempatkan kesadaran sebagai "syarat pertama" bagi terwujudnya usaha-usaha selanjutnya dalam rangka menciptakan masyarakat baru. Sadar berarti menyadari sepenuhnya persoalan dan kesulitan-kesulitan yang dialami masyarakat. "Kesadaran" menjadi aspek yang sangat menentukan sebagaimana yang dikemukakan Fromm sebagai berikut: ${ }^{30}$

"The first equipment in the possible creation of the new society is to be aware of the almost insurmountable difficulties that such

\footnotetext{
${ }^{28}$ Erich Fromm, To Have or To Be, h.153-154

${ }^{29}$ Erich Fromm, To Have or To Be, h. 161

${ }^{30}$ Erich Fromm, To Have or To Be, h.159.
} 
an attempt must face. The dim awareness of this difficulty is probably one of the main reasons that so little effort is made to make the necessary changes". (Kebutuban pertama dalam kemungkinan menciptakan masyarakat baru adalab kesadaran akan kesulitan-kesulitan yang hampir tak dapat teratasi yang berusaba menghadapi. Kesadaran yang samar-samar terhadap kesulitan ini, merupakan salah satu sebab utama sedikitnya usaha yang dilakukan untuk. membuat perubahan yang dibutubkan).

Kesadaran merupakan indikasi sikap realistis yang tidak banyak dimiliki manusia secara umum. Masyarakat dapat mewujudkan semua keinginannya dalam keadaan dan sistem (pemilikan) yang mereka bangun sendiri. Meski demikian, dibalik sikap optimistik, sebenarnya menurut Fromm masyarakat sedang berputus asa karena semua keinginan tersebut tidak mungkin dapat diwujudkan. Masyarakat sebetulnya sedang membangun ilusi. Inilah yang disebut Fromm sebagai fenomena ketidaksadaran. Adapun kesadaran dipahami sebagai suatu keadaan yang bebas dari alienasi sebagimana yang diungkapkannya: "If the economic and political spheres of society are to be subordinated, to human development, the mode of the new society must be determined by the requirement of the the unalienated, being-oriented individua." (Jika bidang politik dan ekonomi harus runduk pada perkembangan manusia, maka model masyarakat baru harus ditentukan oleh kebutuhan-kebutuhan individu yang tak teralienasi dan berorientasi kepada "mengada"). ${ }^{31}$

Hal terpenting selanjutnya adalah, bahwa "mengada" merupakan hasil dari kesadaran. Mengada ditetapkan sebagai model eksistensi yang berarti berupaya meninggalkan model eksistensi lain yang diberlakukan sebelumnya. Semua bentuk hubungan termasuk struktur ekonomi, menurut Fromm harus berorientasi pada mengada. Usaha ini memerlukan perencanaan besar-besaran, berjangka panjang dan bertahap. "Manusia dan masyarakat yang sehat" merupakan tujuan dan harapan bagi usaha strategi budaya. Masyarakat sehat hanya mungkin terwujud jika perubahan radikal diberlakukan, yaitu merealisasikan orientasi mengada dalam kehidupan sehari-hari. Memberlakukan orientasi mengada, berarti membuat perubahan radikal dalam berbagai struktur kehidupan masyarakat. Struktur ekonomi diperhatikan secara khusus oleh Fromm karena pengaruhnya besar bagi "kesehatan"

${ }^{31}$ Erich Fromm, To Have or To Be, h.162. 
masyarakat. Jika suatu masyarakat sehat secara ekonomi, maka akan sehat secara karakterologis, demikian pula sebaliknya. Adapun kenyataan sebelumnya, diandaikan Fromm seperti membangun ekonomi sehat di atas masyarakat yang 'sakit'. ${ }^{32}$

Masyarakat yang sehat memerlukan sistem ekonomi yang sehat. Meski demikian, menurut Fromm usaha besar ini akan berhadapan dengan sejumlah persoalan dan kesulitan-kesulitan. Pertama, bagaimana membangun sebuah model produksi industri tanpa sentralisasi total (sebagaimana yang telah ditunjukkan oleh kapitalisme atau fasisme). Mungkin akan muncul "fasisme dengan wajah tersenyum" (fascism with a smiling face) yang akan mengecoh masyarakat. Kedua, bagaimana mengombinasikan perencanaan menyeluruh dengan sistem desentralisasi dan meninggalkan ekonomi pasar. Ketiga, bagaimana membuang tujuan pertumbuhan untuk pertumbuhan yang selektif. Keempat, bagaimana menciptakan kondisi kerja yang tidak dimotivasi oleh keuntungan materi melainkan oleh kepuasan psikis. Kelima, bagaimana memajukan ilmu tanpa bahaya dalam praktek dan realisasinya. Keenam, bagaimana menciptakan kondisi sejahtera dan gembira, bukan ambisi oleh dorongan nafsu. Ketujuh, bagaimana memberikan rasa aman tanpa tergantung birokrasi. Kedelapan, bagaimana memulihkan inisiatif individu (yang mati), bukan bisnis yang hampir menafikan inisiatif individu. ${ }^{33}$

Berangkat dari kesulitan-kesulitan tersebut, Fromm membuat beberapa pra-syarat bagi pembentukan struktur ekonomi yang sehat: 1) Produksi harus diatur untuk kepentingan "konsumsi yang sehat"; 2 ) Konsumsi sehat akan terwujud jika hak para pemegang saham dan manajemen perusahaan besar yang didasari oleh keuntungan dan ekspansi, dapat dikurangi secara drastis; 3) Setiap individu harus aktif berperan dalam fungsi ekonomis. Artinya harus merealisasikan diri secara penuh dari demokrasi industri dan partisipasi politik yang ada; 4) Partisipasi aktif dalam kehidupan politik memerlukan desentralisasi yang maksimal melalui industri dan politik; 5) Partisipasi aktif dan bertanggungjawab menuntut pergantian manajemen birokratis dengan manajemen humanistis; 6) Melarang segala bentuk indoktrinasi dalam periklanan industri dan politik; 7) Menutup kesenjangan antara bangsabangsa kaya dan miskin; 8) Pembebasan perempuan dari dominasi patriakal; 9) Membentuk suatu dewan kebudayaan yang bertugas

\footnotetext{
${ }^{32}$ Erich Fromm, To Have or To Be, h.162.

${ }^{33}$ Erich Fromm, To Have or To Be, h.159-160.
} 
menasihati pemerintah, para politikus dan warga negara dalam segala keperluan pengetahuan; 10) Membentuk suatu sistem informasi yang efektif; 11) Memisahkan penyelidikan ilmiah dari penerapannya dalam industri dan pertahanan. ${ }^{34}$

Ada beberapa indikasi yang memberi peluang dan semangat bagi realisasi masyarakat baru, yaitu: Pertama, semakin banyak manusia yang mengakui kebenaran dan memandang perlu etika baru bagi pertumbuhan ekonomi yang lebih 'manusiawi' terhadap manusia dan alam. Kedua, semakin meningkat rasa tidak puas masyarakat terhadap struktur sosial yang berlaku yang ditunjukkan dalam berbagai ekspresi. Ketiga, hanya sebagian kecil manusia saja yang dikuasai model memiliki, sebagian kecil lainnya dikuasai mengada. Adapun sebagian kecil lain ditentukan oleh struktur sosial mengada atau memiliki (Fromm, 1981: 182-186). Keempat, tingginya tingkat alienasi yang menimpa seluruh lapisan (kelas) masyarakat menyadarkan akan pentingnya perubahan karakter yang akan mengubah sejumlah kenyataan, seperti karakter pasar akan berabah menjadi karakter yang produktif, agama sibernetik akan berubah menjadi agama humanistik radikal dan Kota Kemajuan masyarakat modern akan berabah menjadi Kota Mengada. ${ }^{35}$

\section{Strategi Budaya sebagai Kekuatan Pemikiran Fromm}

Pandangan Fromm tentang strategi budaya, memperlihatkan kekuatan pemikirannya yang meliputi: Pertama, Fromm merupakan sosok pemikir kritis. Bentuk kritisnya dapat dilihat pada bagaimana Fromm menyikapi dua pemikiran yang banyak mempengaruhinya, seperti Freud dan Marx. ${ }^{36}$ Cara-cara kritis keduanya dalam melihat individu dan masyarakat, dikritisi kembali oleh Fromm sehingga menjadi sebuah sintesis. Pertautan dan pergulatan kritis keduanya di dalam pemikiran Fromm digambarkan dalam Beyond the Chains of illussions. Fromm mengkritisi keterpengaruhannya atas psikoanalisis dan metodologi Freud pada tahun 1930-an yang merupakan sebuah masa paling penting bagi revisi psikoanalisis Freud. Adapun sikap kritisnya terhadap Marx terlihat dari seleksi yang dilakukannya. Meskipun Fromm dianggap sebagai penerjemah pemikiran Marx, terutama untuk karya Marx Economical and Pbilosophical Manuscript of 1844, namun tidak semua

\footnotetext{
${ }^{34}$ Erich Fromm, To Have or To Be, h.162-182.

${ }^{35}$ Erich Fromm, To Have or To Be, h.182-187.

${ }^{36}$ Rainer Funk, Erich Fromm: The Courage To Be Human, (New York: Continuum: 2002), h. ix.
} 
gagasan Marx dapat diterimanya. Contoh yang dapat dikemukakan, tentang pendiriannya yang tidak terlalu setuju dengan pandangan Marx tentang eksistensialisme humanis dan tentang teori-teori sosiologi dan ekonomi. Fromm juga mengkritik Marx dengan menganggap Marx gagal melihat sejauh mana kapitalisme mampu memodifikasi diri dan memenuhi kebutuhan ekonomi negara-negara industri. Marx juga telah dianggap gagal melihat bahaya birokratisasi, sentralisasi serta sistem otoritarian yang terjadi tidak saja dalam sistem kapitalisme, melainkan juga dalam sistem sosialisme. ${ }^{37}$

Kedua, Pemikiran Fromm berorientasi sosia yang bersifat khusus. Kekhususannya terletak pada penempatannya terhadap daya-daya psikis manusia yang menghantarkan pada kesadaran utuh yang tidak hanya bercermin dari kesadaran sosial dan gagasan-gagasan, bukan pula merupakan hasil langsung dari dasar ekonomi, melainkan merupakan sesuatu yang dimediasikan oleh daya-daya psikis yang dalam hal ini berupai daya-daya produktif. Funk menyebut pendekatan Fromm ini sebagai "psikologi sosial". Persoalan terpenting dalam pendekatan ialah bagaimana individu mampu menjadi makhluk sosial dan secara otomatis mampu berhubungan dengan manusia lain dan diri sendiri dalam suatu cara yang terarah pada tujuan kemanusiaan, seperti perkembangan cinta, nalar dan kerja produktif. ${ }^{38}$

Orientasi sosial Fromm tidak lepas dari ketertarikannya yang kuat terhadap pemikiran Marx. Ada beberapa alasan ketertarikannya. Pertama, filsafat Marx dianggap merepresentasikan sebuah protes untuk menentang alienasi manusia, mengembalikan hilangnya jati diri manusia dan menentang perubahan manusia menjadi benda. Kedua, Fromm menganggap Marx menempatkan manusia secara konkret, yaitu dengan memandang manusia sebagai kelas sosial yang perkembangannya dibantu oleh masyarakat. Ketiga, pemikiran Marx merupakan sumber wawasan filosofis yang dapat menjadi penangkal atas kondisi kejumudan sosial yang sedang berlangsung, baik secara terbuka maupun tertutup. Faktor-faktor tersebut membuat Fromm memandang Marx sebagai pemikir yang lebih ulung daripada Freud. Fromm menggunakan Freud hanya dalam rangka mengisi kekurangan pemikiran Marx. Jika dicermati dengan seksama, antara analisis kritis, polemik Fromm tentang

${ }^{37}$ Rainer Funk, Pengantar, dalam, Erich Fromm, "Beyond the Chains of Illusion, Pertemuan Saya dengan Marx dan Freud”, (Yogyakarta: Jendela, 2002), cetakan pertama, h. ix; dan Erich Fromm, To Have or To Be, h. x.

${ }^{38}$ Rainer Funk, Pengantar, dalam, Erich Fromm, "Beyond the Chains of Illusion, h.ix. 
kepribadian Freud dan keterpengaruhannya terhadap Freud, terlihat perbedaan yang jelas melalui kata-kata pujian yang ditujukan kepada Marx. Bertolak dari sikap Fromm tersebut, Hall dan Lindzey menyebut Fromm sebagai "teoritikus yang berkepribadian Marxian". ${ }^{39}$

Ketiga, konsep Fromm tentang strategi budaya yang merupakan perwujudan pendekatan sosial Marx, bersifat 'dinamis'. Perkembangan yang terjadi, berlangsung secara terus-menerus. Hubungan antara elemenelemen yang terdapat di masyarakat, seperti karakter sosial dan struktur sosial tidak akan statis dan berhenti, tetapi terus berjalan, saling berhadapan dan saling mempengaruhi. ${ }^{40}$ Jika kedua unsur tersebut dikembangkan menjadi unsur-unsur, seperti: ekonomi, politik, psikologis, filosofis dan spiritual yang saling berinteraksi dan berinterelasi, maka seluruhnya akan mengarah pada suatu perubahan simultan (bersamaan). Pembaharuan yang hanya terpaku pada salah satu bidang seperti ekonomi, hanya akan merusak semua perubahan dan "masyarakat yang baik" tak akan dapat terwujud. ${ }^{41}$ Strategi budaya harus diusahakan secara bersama-sama oleh para pembuat kebijakan dan para pemikir terbaik dari berbagai lapisan masyarakat dengan tujuan yang jelas, yaitu ingin menciptakan masyarakat yang lebih baik. Secara eksplisit Fromm menegaskan, bahwa perkembangan manusia adalah proses kelahiran yang terus berlanjut dan proses kebangkitan yang terus berlanjut. ${ }^{42}$

Keempat, pemikiran Fromm bercorak humanis, yaitu berorientasi pada manusia. Laurentia menyebutnya sebagai "psikoanalis humanistik dari kelompok Frankfurt" 43 . Fromm memandang realitas ideal akan tercapai jika melakukan perubahan mendasar pada struktur masyarakat industrial dan menghidupkan kembali humanisme yang fokus pada realitas nilai-nilai yang sungguh-sungguh hidup. Bagi Fromm, tidak ada otoritas, termasuk Tuhan dalam pengertian apapun sebagaimana yang dikemukakan teologi, filsafat atau sejarah yang mampu memahami manusia, kecuali manusia itu sendiri karena hanya manusia yang mampu menemukan tujuan kehidupan dan menemukan cara merealisasikannya.

${ }^{39}$ Erich Fromm, To Have or To Be, h. v-vii, Lihat pula, S. Calvin Hall \& Gamey Linndzey, Teori-Teori Psikodinamik (Klinis), terj. Supratiknya, (Yogyakarta: Kanisius, 1993), h. 256.

${ }^{40}$ Erich Fromm, To Have or To Be, h. 120.

${ }^{41}$ Erich Fromm, Masyarakat yang Sehat, h. 307.

${ }^{42}$ Erich Fromm, To Have or To Be, h. 160-161 dan Erich Fromm, "Beyond the Chains of Illusion, h. 241.

${ }^{43}$ T. Laurentia, Erich From, dalam Paulus Budiharjo (ed..) "Mengenal Teori Kepribadian Mutakhir", (Yogyakarta: Kanisius, 1997), h. 72. 
Meskipun apa yang ditemukan manusia tidak mutlak, tetapi manusia dapat berusaha memperoleh pengalaman, tingkatan, intensitas dan kejelasan yang akan memberikan kekuatan menjalani kehidupan nyata. Manusia mampu menggambarkan pengalaman dengan menyadari individualitasnya dan dapat menempatkan dirinya dalam dua tempat paradoksal, yaitu di satu sisi merealisasikan individualitasnya, sekaligus melampauinya mencapai pengalaman universal. Bagi Fromm, hanya manusia yang mampu mengembangkan diri dan sepenuhnya dapat melepaskan ego. ${ }^{44}$

Satu hal terpenting dari ide humanismenya adalah apa yang disebutnya dengan humanitas, yaitu bukan sesuatu yang mengacu pada hal abstrak, melainkan mengacu pada kenyataan. Semua humanitas (bumanity) berisi individu-individu dan semua individu adalah sama dalam hal kualitas fundamental kemanusiaan. ${ }^{45}$ Konsep Fromm tentang kesamaan manusia berakar dari tradisi Judaeo-Kristiani, baik Perjanjian Baru atau Lama. Dari sini, berkembang keyakinannya tentang "humanisme-normatif" yang memandang semua manusia normatif dalam berperilaku. Bertolak dari hal tersebut berkembang pula pandangan Fromm tentang "humanisme etis" yang menganggap manusia terarah pada prinsip baik-buruk yang ditentukan dirinya sendiri, bukan pada otoritas di luar dirinya. ${ }^{46}$ Kemudian dari sisni lahir pandangan Fromm tentang "humanisme relegius" yang menganggap manusia selalu mengarahkan pengalaman pada kerinduan akan makna dan nilai-nilai ultim dan sejati. ${ }^{47}$ Kecenderungan relegius terlihat dalam pikiran Fromm tentang mengada, bahkan mengada merupakan esensi etos religiusnya, apalagi diambil dari Empat Kebenaran Mulia Budha yang sarat dengan nilai relegius. ${ }^{48}$

Kelima, terobosan bagi tradisi psikoanalisis. Menurut Laurentia, hal ini merupakan bagian terpenting di antara semua kekuatan Fromm. Fromm telah berhasil membuat sebuah terobosan unik bagi tradisi psikoanalisis dengan memberi perhatian pada dimensi kultur, sejarah dan sosio-ekonomi untuk menganalisis karakter individu dan sosial. Jika

${ }^{44}$ Erich Fromm, "Beyond the Chains of Illusion, h. 235-247.

${ }^{45}$ Rainer Funk, Pengantar, dalam, Erich Fromm, "Beyond the Chains of Illusion, h. 85-87.

${ }^{46}$ Erich Fromm, Manusia Bagi Dirinya, terj. "Man For Him Self, Eno Syafruddin, (Jakarta: Akademika, 1988), h. 12.

47 Erich Fromm, 1966, Marx Concept of Man, (New York: Fredrick Ungar Publishing Co.1966), h. 180.

${ }^{48}$ Rainer Funk, Pengantar, dalam, Erich Fromm, "Beyond the Chains of Illusion, h. 264274. 
dibandingkan rekan-rekan Fromm yang hanya bergelut dalam aspek psikis internal (inner psychology), Fromm merupakan salah satu di antara segelintir ahli yang menaruh perhatian besar pada masalah-masalah global, seperti modernitas dan implikasinya terhadap perkembangan psikis manusia. Kekayaan pengetahuan studi-studi Fromm terhadap kebudayaan, antropologi, sosiologi dan sejarah, telah berhasil keluar dari tradisi psikoanalisis ortodoks dan tidak terjebak dalam perspektif psikologis yang sempit. ${ }^{49}$

\section{Relevansi Pemikiran Fromm bagi Strategi Budaya Nasional}

Kompleksitas persoalan pembangunan Indonesia mendesak perlunya disusun sebuah strategi budaya baru. Adapun strategi budaya yang tepat bagi Indonesia menurut Puspowardoyo adalah strategi budaya yang memperhatikan beberapa hal pokok berikut ini: $:{ }^{50}$ Pertama, strategi budaya harus mengandung muatan persepsi budaya komprehensif yang mempunyai cakupan luas terhadap peri-kehidupan masyarakat Indonesia. Cakupan luas meliputi semua bidang budaya, seperi: antropos (manusia secara individual), oikos (kosmis tempat manusia hidup dan menjalankan proses pembudayaan), tekne (peralatan yang digunakan sebagai perpanjangan tangan untuk mengerjakan aktivitas dunianya) dan ethnos (komunitas sebagai wadah manusia berinteraksi dengan sesamanya). Kedua, strategi harus berorientasi ke depan untuk menghadapi masa yang akan datang dengan segala masalah dan tantangannya. Masa lalu selayaknya ditafsirkan secara kreatif. Strategi budaya harus mampu memberikan optimisme serta menanamkan rasa kebanggaan dan kepercayaan akan kemampuan bangsa sendiri untuk mengatasi permasalahan. Ketiga, strategi budaya diarahkan untuk meningkatkan kualitas hidup masyarakat baik secara jasmani maupun rohani. Perlu dibuat usaha-usaha dalam rangka menyediakan, memperbanyak, memperluas dan meningkatkan sarana - prasarana yang menyangkut seluruh sektor kehidupan dengan dukungan ilmu, teknologi dan sistem pengelolaan yang baik. Sarana dan prasarana mempunyai kedudukan instrumental yang hanya akan bermakna sejauh diarahkan untuk kepentingan manusia. Suatu finalitas dalam sarana dan prasarana

49 T. Laurentia, Erich From, dalam Paulus Budiharjo (ed..), h. 72-73.

${ }^{50}$ Soerjanto Poespowardojo, Refleksi Budaya Mengenai Pembangunan Nasional, dalam, (red.) Budhi Munawar Rachman dan F.X.B. Tulus Wardaya,SJ., "Indonesia dan Masalah-Masalah Pembangunan", (Jakarta: KSP-STF Driyakara dan The Asia Fondation, 1986), h. 187-205. 
perlu diartikulasikan, sedangkan arti dan makna manusiawi akan terwujud sejauh manusia mampu mentransformasikannya ke dalam diri sehingga mutu dan taraf hidup masyarakat ditingkatkan. Melalui upaya tersebut diharapkan akan terjadi suatu perubahan dalam kehidupan manusia menuju tingkat yang lebih baik.

Hal penting lain yang digarisbawahi oleh Soerjanto adalah bahwa strategi budaya dirumuskan sebagai usaha menciptakan tingkat dan suasana kehidupan masyarakat yang mandiri. Mandiri berarti tidak menyandarkan diri pada kebaikan masyarakat atau bangsa lain atau tidak menjadikan bantuan bangsa lain sebagai tumpuan hidup. Kehidupan yang mandiri pada hakikatnya menunjukkan adanya kepribadian. Artinya, tidak tenggelam dalam arus sarana dan prasarana yang senantiasa mengalir dalam arus komunikasi modern, melainkan dapat merelaktivikasikannya dengan diri pribadi sebagai manusia dan sebagai ukuran. Substansi strategi budaya perlu dijabarkan ke dalam eksistensi masyarakat Indonesia yang pada hakikatnya terwujud dalam dua unsur utama yaitu sebagai pelaku (actor) dan sebagai tatanan atau struktur (structure). ${ }^{51}$

Berpijak pada persoalan-persoalan pembangunan nasional dan beberapa ketentuan pokok yang penting bagi strategi budaya nasional, gagasan strategi budaya Fromm menjadi relevan untuk dikemukakan. Pemikiran Fromm relevan bagi pembangunan Indonesia, baik secara sosial maupun secara intelektual. Secara intelektual gagasan Fromm relatif telah diterima oleh banyak kalangan akademisi di Indonesia dilihat dari respons peminat buku-buku dan pengkajinya. Secara sosial, gagasan Fromm sesuai dengan pokok persoalan pembangunan di Indonesia. ${ }^{52}$ Krisis orientasi telah terjadi di Indonesia sehingga mengakibatkan terjadinya berbagai, seperti: korupsi, kolusi, nepotisme, kekerasan, konflik sosial, terorisme dan lain sebaginya memerlukan strategi budaya baru menggantikan strategi budaya yang berlaku selama ini. Sebagaimana yang telah diungkapkan oleh Sumarto dalam pembahasan sebelumnya, persoalan mental yang terjadi di negara Indonesia dapat dianggap relatif parah akibat pembangunan nasional selama ini terlalu berorientasi material, sementara yang non-material terabaikan. Perilaku, gagasan dan tujuan pembangunan yang selama ini berjalan terbentuk oleh dominasi orientasi ekonomi sehingga apa yang disebut dengan norma-

${ }^{51}$ Soerjanto Poespowardojo, Refleksi Budaya Mengenai Pembangunan Nasional, h. 207.

${ }^{52}$ Kleden, Ignas, Sikap Ilmiah dan Kritik Kebudayaan, L(Jakarta: LP3ES, 1987), cetakan pertama, h. xiv. 
norma maupun nilai-nilai baik yang bersifat formal atau non-formal tersisihkan. Mental masyarakat yang terbentuk oleh dominasi faktor material seperti sistem ekonomi, telah terbukti tidak menjamin terciptanya masyarakat yang damai dan sejahtera.

Tawaran strategi budaya Fromm memperhatikan dua aspek mendasar yaitu material (seperti: ekonomi) dan memprioritaskan aspek mental yang dalam bahasa Fromm disebut dengan 'karakter', menjadi relevan bagi pembangunan nasional. Para pembuat kebijakan negara perlu merubah orientasi pembangunan dan memulai penerapannya dari individu mereka. Jika gagasan Fromm diterapkan, perubahan pertama yang akan tampak adalah perubahan mental kemudian diikuti oleh perubahan gagasan - tujuan pembangunan nasional dan selanjutnya perubahan struktur ekonomi. Perubahan yang diharapkan Fromm bukan sebaliknya yang berawal dari perubahan struktur ekonomi yang berimbas pada terbentuknya karakter sosial yang "sakit". Mengada yang identik dengan sifat-sifat produktif, seperti: kreatif, mandiri, cinta, pemberi dan dinamis diperlukan masyarakat Indonesia. Sifat-sifat tersebut sebagai pengganti mental memiliki yang identik dengan sifat-sifat non-produktif, seperti: reseptif (penerima), eksploitatif (serakah), menimbun dan berorientasi pasar. Meskipun sifat-sifat produktif yang berpijak pada orientasi mengada menjadi fokus utama pemikiran Fromm, tidak manandakan pengabaian orientasi memiliki. Secara eksistensial, memiliki dibutuhkan bangsa Indonesia karena salah satu kemampuan bangsa Indonesia tercermin dari harta kekayaan yang dimilikinya, seperti berupa asset-aset nasional. Inilah yang disebut dengan aspek having pembangunan Nasional oleh Soerjanto. ${ }^{53}$ Terdapat satu aspek penting lain yang menuntut perhatian serius, yaitu apa yang disebutnya dengan "harkat dan martabat bangsa Indonesia" yang aktualitasnya tergantung pada sejauh mana realisasi mengada dalam kehidupan berbangsa dan bernegara. Sartono menyebut hal penting tersebut dengan "kepribadian bangsa" yang terdiri dari beberapa unsur, yaitu: kebudayaan nasional yang mencakup seluruh kebudayaan Indonesia, baik bersifat lokal maupun nasional, identitas nasional berupa pengalaman kolektif bangsa dan sejarah yang mengalami kristalisasi sehingga membentuk identitas bersama, etos bangsa, yaitu totalitas nilai-nilai hidup yang membentuk pola kelakuan serta gaya hidup bangsa dan nasionalisme, yaitu pelembagaan nilai-nilai bersama, seperti Pancasila dalam kehidupan berbangsa. Seluruh upaya tersebut bertumpu pada perubahan mental.

53 Soerjanto Poespowardojo, Refleksi Budaya Mengenai Pembangunan Nasional, h. 209. 
Strategi budaya mengada merupakan tawaran yang patut dipertimbangkan agar bangsa Indonesia dapat keluar dari kemelut ekonomi, sosial dan politik serta dilema persoalan pembangunan nasional selama ini. ${ }^{54}$

Hal terpenting lain yang perlu diperhatikan adalah, bahwa mengada dapat dijadikan sebagai alat kritik atas dominasi kapitalisme di Indonesia. Kapitalisme mendominasi dalam bidang ekonomi, terutama berbentuk ketergantungan terhadap bantuan dana internasional. Ketergantungan ini semakin menguat dengan semakin memburuknya kondisi sosial, politik dan ekonomi akibat krisis dalam berbagai bidang yang melanda Indonesia. Indonesia telah terjebak oleh sistem ekonomi kapitalisme sehingga sulit untuk keluar. Padahal sebagaimana yang telah disinggung pada bab sebelumnya, kapitalisme sarat dengan orientasi memiliki. Orientasi memiliki disadari atau tidak telah merasuki masyarakat kita mulai dari masyarakat biasa hingga tingkat pemegang kekuasaan. Akibatnya, konflik kepentingan terjadi mulai dari masyarakat di tingkat yang paling rendah hingga yang tertinggi. Mengada dapat membantu, paling tidak untuk menggugah kesadaran akan kenyataan persoalan Indonesia. Kesadaran akan menghantarkan masyarakat untuk selalu berpikir dan bersikap kritis dalam melakukan sesuatu yang bermakna bagi bangsa ini. Kondisi yang lebih baik bagi bangsa Indonesia merupakan sesuatu yang mungkin dapat diwujudkan sebagaimana optimistis Fromm: "saya percaya babwa perkembangan manusia adalah proses.....yang akan terus berlanjut."

\section{Penutup}

Inti temuan yang dihasilkan adalah, bahwa strategi budaya Fromm berpijak pada konsep mengada (to be). Mengada sebagai sebuah cara berada eksistensial manusia bercirikan aktif, yaitu optimal menggunakan kekuatan-kekuatan manusiawi untuk produktif. Produktif berarti cenderung pada perubahan, terararah pada kebaikan, memberi dan mencintai. Mengada juga suatu model eksistensi khas manusia yang bersifat mandiri, bebas dan kritis. Aktif juga diartikan sebagai kecenderungan dinamis secara lahir dan batin, yaitu mengekspresikan segenap kemampuan dan bakat-bakat manusiawi untuk senantiasa memperbaharui diri sendiri, selalu tumbuh berkembang, mengalir dan

\footnotetext{
${ }^{54}$ Kartodirdjo, Sartono, Strategi Pembangunan Sosial-Budaya dan Prospek Masa Depan, (Yogyakarta: Makalah P3K-UGM, 1989), h.26.

${ }^{55}$ Erich Fromm, Beyond the Chains of Illusion, h. 241.
} 
mengatasi penjara ego. Bagi perspektif mengada, aku didefinisikan sebagai siapa aku, bukan apa yang aku miliki.

Dari konsep mengada tersebut dibangun rumusan trategi budaya, yaitu suatu usaha menciptakan kebudayaan baru meliputi aspek material dan non-material. Aspek material meliputi: struktur sosial, ekonomi dan politik, sedangkan aspek non-material meliputi: karakter individualsosial, gagasan dan tujuan masyarakat yang berupa: norma-norma, nilainilai, dogma, ideologi dan lain sebagainya. Aspek-aspek tersebut saling berinteraksi dan saling mempengaruhi. Orientasi mengada akan mempengaruhi struktur ekonomi, kemudian membentuk karakter sosial dan selanjutnya membentuk gagasan. Kemudian siklus berjalan sebaliknya dalam rangkaian relasional yang dinamis.

Tawaran strategi budaya Fromm yang berpijak pada orientasi mengada, relevan bagi pembangunan Indonesia, baik secara intelektual maupun secara sosial. Secara intelektual gagasan Fromm telah hadir sebagai kajian filsafat yang menampilkan sisi psikoanalis dan sosiologisnya yang khas. Upaya sintesis yang diupayakan Fromm ini telah memberi nuansa baru bagi pengkaji filsafat Indonesia untuk kemudian diterjemahkan dalam realitas keindonesiaan. Adapun secara sosial, gagasan Fromm dapat membantu mengurai kebuntuan pembangunan nasional yang disebabkan oleh problem mental yang sampai saat ini belum terselesaikan, seperti makin menguatnya perilaku koruptif di setiap lini, maraknya kolusi, nepotisme, kekerasan, konflik sosial, terorisme, narkoba dan lain sebaginya. Pembangunan nasional selama ini terlalu berorientasi material (to have) dan mengabaikan aspek non-material yang mencakup perilaku, gagasan dan tujuan pembangunan. Akibatnya, aspek ini justru yang menjadi kendala dan bom waktu bagi pembangunan. Strategi budaya Fromm dengan orientasi mengadanya (to be) akan akan membantu pembangunan nasional memperkuat fondasi fundamentalnya dan pada gilirannya pembangunan dapat berjalan sesuai arah dan tujuan yang diharapkan.

\section{Daftar Pustaka}

Bakker, A., 1992, Ontologi atan Metafisike Umum, Kanisius, Yogyakarta. Boivin, Rene, 1968, Erich Fromm: Concept of Man, Campus of Joiquire's printing Press, Canada.

Freud, Sigmund, 1984, Memperkenalkan Psikoanalisa, terj. "Ueber Psychoanayse, Funf Vorlesungen”, Kees Bertens, Gramedia, Jakarta. 
2002, Peradaban dan Kekecewaan, terj. "Civilization and Its Discontents”, Apri Danarto, Jendela, Yogyakarta. Cetakan pertama.

Fromm, Erich, 1963, The Art of Loving, Bantam, USA. , 1966, Marx Concept of Man, Fredrick Ungar Publishing Co, New York. 1968, The Revolution of Hope, Harper Colophon Books, USA. ,1969, You Shall Be As Gods, Fawcett Primer, New York. ,1981, To Have or To Bel, Bantham Book, USA, edition 1. ,1987, Memiliki dan Menjadi, terj. "To Have or To Be?”, Soesilohardo, LP3ES, Jakarta.

,1988, Manusia Bagi Dirinya, terj. "Man For Him Self, Eno Syafruddin, Akademika, Jakarta. ,1995, Masyarakat yang Sebat, terj. "The Sane Society”, Thomas Bambang Murtianto, Yayasan Obor Indonesia, Jakarta, edisi pertama.

1999, Lari Dari Kebehasan, terj. "Escape From Freedom”, Kamdani, Pustaka Pelajar Ofset, Yogyakarta.

, 2001, Konsep Manusia Menurut Marx, terj. “Marx's Concept of Man", Agung Prihantoro, Pustaka Pelajar Ofset, Yogyakarta.

2002, Beyond the Chains of Illusion, Pertemuan Saya dengan Marx dan Freud, terj. "Beyond the Chains of Illusions; My Encounter with Marx and Freud", Yuli Winarno, Jendela, Yogyakarta, cetakan pertama.

2002, The Art of Listening: Kritik atas Psikoanalisa Sigmund Freud, terj. "The Art of Listening", Apri Danarto, Jendela, Yogyakarta, cetakan pertama.

Funk, Rainer, 1982, Erich Fromm: The Courage To Be Human, Continuum, New York.

, 2002, Pengantar, dalam, Erich Fromm, "Beyond the Chains of Illusion, Pertemuan Saya dengan Marx dan Freud", Jendela, Yogyakarta, cetakan pertama.

Hall, S. Calvin \& Linndzey, Garney, 1993, Teori-Teori Psikodinamik (Klinis), terj. “Theories of Personality”, Supratiknya, Kanisius, Yogyakarta. Horkheimer, Marx, 1972, Critical Theory, Seabury Press, USA. 
Johnson, Doyle Paul, 1994, Teori Sosiohgi, Klasik dan Modern, terj. Robert M.Z. Lawang, Gramedia, Jakarta.

Kartodirdjo, Sartono, 1989, Strategi Pembangiman Sosial-Budaya dan Prospek Masa Depan, Makalah P3K-UGM, Yogyakarta.

Kleden, Ignas, 1987, Sikap Ilmiah dan Kritik Kebudayaan, LP3ES, Jakarta, cetakan pertama.

Koesbyanto, Dhanu, J.A, dan Adi Yuwono, Firman, 1997, Pencerahan: Suatu Pencarian Makna Hidup dalam Zen Budhisme, Kanisius, Yogyakarta.

Laurentia, T., 1997, Erich From, dalam Paulus Budiharjo (ed.) "Mengenal Teori Kepribadian Mutakhir", Kanisius, Yogyakarta, cetakan pertama.

Marcel, Gabriel, 1965, Being and Having, The Fontana Library, Theology and Philosophy.

Marx, Karl, 1957, Capital, Volume I and II, J. M. Dent and Son's Ltd, London.

Peursen, Van, 1988, Strategi Kebudayaan, terj. "Strategic Van De Cultuur", Dick Hartoko, Kanisius, Yogyakarta.

Poespowardojo, Soerjanto, 1986, Refleksi Budaya Mengenai Pembangunan Nasional, dalam, (red.) Budhi Munawar Rachman dan F.X.B. Tulus Wardaya,SJ., "Indonesia dan Masalah-Masalah Pembangunan", KSP-STF Driyakara dan The Asia Fondation, Jakarta.

Sastrapratedja, 1987, Orientasi Hidup: Memiliki atau Mengada?, dalam Erich Fromm, "Memiliki dan Menjadi, Tentang Dua Modus Eksistensi”, terj. “To Have or To Be”, F. Soesilohardo, LP3ES, Jakarta.

Sindhunata, 1983, Dilema Usaha Manusia Rasional, Gramedia, Jakarta.

Sumarto, Sukarno, 1994, Konsep Kebudayaan Modern, dalam Johanes Mardimin (ed.) "Jangan Tangisi Tradisi, Tranformasi Budaya Menuju Masyarakat Indonesia Modern”, Kanisius, Yogyakarta, cetakan pertama.

Suseno, Franz Magnis, 1992, Filsafat Sebagai Ilmu Kritis, Kanisius, Yogyakarta, cetakan pertama.

2001, Pemikiran Karl Marx, dari Sosialisme Utopis ke Perselisihan Revisionisme, Gramedia, Jakarta, cetakan kelima. 
Sutikna, Nana, 1996, Keterasingan Manusia (Alienasi) Menurut Erich Fromm, tesis, Fakultas Filsafat, Pascasarjana, UGM, Yogyakarta.

Wiggershaus, Rolf, The Frankfurt School: Its History, Theories, and Political Significance, Polity Press, Cambridge. 